\title{
Musty and Moldy Taint in Wines: A Review
}

\author{
Maria Carla Cravero \\ CREA, Council for Agricultural Research and Economics, Research Centre for Viticulture and Enology, \\ Via Pietro Micca, 35, 14100 Asti, Italy; mariacarla.cravero@crea.gov.it
}

Received: 19 February 2020; Accepted: 1 June 2020; Published: 16 June 2020

\begin{abstract}
The literature about musty and moldy taint - the so-called cork taint-in wines is varied because there are many different molecules involved in this wine defect. Chloroanisoles are the most relevant compound responsible for cork taint and of these, 2,4,6-trichloroanisole (TCA) is the most common, but 2,3,4,6-tetrachloroanisole (TeCA) and 2,4,6-tribromoanisole (TBA) can also be responsible of this defect. For other compounds involved in cork taint, geosmin and 2-methylisoborneol (2-MIB) are responsible for earthy off-flavor; pyrazines cause vegetable odors, and guaiacol results in smoked, phenolic and medicinal defects. Off-odors of mushroom in wines are caused by 1-octen-3-ol and 1-octen-3-one coming from grapes contaminated by bunch rot (Botrytis cinerea). The sensory aspects of these molecules are illustrated in this review. Generally, the most important cause of this wine contamination is the natural cork of bottle stoppers, but this is not always true. Different origins of contamination include air pollution of the cellars, wood materials, barrels and chips. A review of the possible prevention or remedial treatments to cork taint is also presented. The best solution for this off-flavor is to prevent the wine contaminations.
\end{abstract}

Keywords: moldy taint; cork taint; TCA; TBA; geosmin; 2-methylisoborneol; pyrazines; guaiacol; 1-octen-3-ol; 1-octen-3-one

\section{Musty and Moldy Taint}

Musty and moldy taint in wine is an important off-flavor in the wine production, generally correlated to the cork stoppers used to plug the wine bottles. Cork taint is a pervasive problem in the industry and is known as "gout de bouchon" in French "gusto di tappo" in Italian-literally "taste of cap." Although commonly called cork taint, it is not always caused by cork stoppers.

Cork stoppers were used for many years in wine industry and they are still very important because many consumers in Europe and China still associate them with high quality wine. After the introduction of competitive caps made of synthetics, screws and glass, manufacturers invested considerable resources to improve the quality of cork caps.

Cork oak (Quercus suber L.) forest cultivation is an important economic activity in many Mediterranean countries; it is cultivated on about two million hectares-61\% in Spain and Portugal, $33 \%$ in Morocco, Algeria and Tunisia and 6\% in Italy and France [1]. Cork oak usage is correlated to the preservation of biodiversity and the reduction of $\mathrm{CO}_{2}$ emissions. The harvest of the cork bark does not necessitate tree cutting because the rhytidome has high insulation capacity; as such, this species produces suckers to recover quickly after a fire and to resist cold and wind [1]. Cork oak forest cultivation contributes to the protection of the soil, the creation of the landscape and the regulation of hydrological cycle [2]. Cork regenerates after each stripping, and the cork tree can survive the bark loss of more than $50 \%$ [3]. Moreover, it is a natural, renewable, recyclable and non-toxic resource. Cork oak is used to produce stoppers, but it has many other applications in many different manufacturers industries, included automobile and aeronautical industries [3]. Moreover, granulated cork is also the base material for the production of agglomerated corks for beverages. 
Specialists can distinguish between "true cork taint" and "moldy off-flavors" [4]. Cork taint is very rare; it causes a very unpleasant and putrid odor in wines, and its cause remains unknown. It was speculated that mancha amarela-yellow spot—macchia gialla—can attack Q. suber L. and modify mechanical, structural and optical properties of cork causing moldy off-flavor in wine. The cellular structures of infected and healthy tissues of cork are different [5], and contaminated cork should not be used in stopper production.

The most common compound responsible for cork taint is 2,4,6-trichloroanisole (TCA), but other compounds like 2,4,6-tribromoanisole (TBA), 2,3,4,6-tetrachloroanisole (TeCA), 1-octen-3-ol, 1-octen-3-one, 2-methylisoborneol, geosmin, pyrazines or guaiacol can be also involved [4]. Anisoles, especially TCA, are responsible for at least $80 \%$ of the cases of cork taint [6].

Studies found that moldy-off flavor can be caused by different compounds, and the contamination of the wine is not always attributable to the cork stoppers. It can take place starting from the grapes up to wine storage in the cellar [4]. In the OIV (The International Organization of Vine and Wine) document on Sensory Analysis of Wine (http://www.oiv.int/public/medias/3307/review-on-sensoryanalysis-of-wine.pdf), this type of defect is not connected directly to cork.

Cork taint can affect $0.5 \%$ and $7 \%$ of wines and the estimated cost of cork-related wine spoilage can be over several billions of dollars per year [6]. Defects related to the cork cap depreciate the wine and are often the subject of legal disputes between the buyer who suffered the damage and the company that provided them, which often has an insurance policy against this. If the cause is the cork cap generally only a few bottles are affected, while if the cause is another-materials used in the construction of cellars, wooden beams or barrels-the damage can be to the whole production and it can be much more serious.

In Table 1 are reported the most important molecules involved in the so-called "cork taint" and the corresponding references cited in this review.

\section{Haloanisoles}

\subsection{2,4,6-Trichloroanisole (TCA)}

TCA is the most pervasive of the haloanisoles compounds affecting cork taint in wine composition. The presence of TCA can depreciate the wine, impairing olfactory or gustative wine characteristics even in quantities lower than the identification threshold. The average consumer may not attribute the depreciation of the product to the cork stopper and therefore attaches it to the wine. TCA is a potent suppressor of olfactory signal transduction at $10-15 \mathrm{~mol} \mathrm{~m}^{-3}$ TCA concentrations-extremely low for detection [7].

TCA produces unpleasant odors of mold and wet cardboard to foods and beverages including beer, milk, water, dried fruit, cocoa powder, fish and shellfish. It is the cause "Rio defect" in coffee from Central and South America with odors describes as medicinal, phenolic or iodine-like [8]. In brewing beer, TCA causes a typical odor of mold and damp cellar that can contaminate water and other raw materials. TCA can develop on the premises of the brewery or derive from packaging materials [9]. Under experimental conditions with artificially contaminated cork stoppers, TCA migration increased with contact surface, temperature and time [10]. However, characteristics common to all naturally polluted cork stoppers were not identified. The characteristics of each cork stopper influenced the TCA concentrations.

TCA and other chloroanisoles are attributed to many types of mold that produce moldy-off-flavors in wine. Armillaria mellea is considered to be responsible for the presence of chloroanisoles in various origins of cork; however, no chloroanisole contamination was found in a recent study on Extremadura cork [11]. The importance of the geographical origin of cork and the function of A. mellea in the formation of chloroanisoles are still not completely clear. Some results [12] showed that the fungi quantitative contamination was similar in TCA-contaminated and uncontaminated cork stoppers, but the number of the fungal species was higher in the last category. They observed that Paecilomyces 
spp., Penicillium chrysogenum, Penicillium glabrum and Trichoderma viride produced the highest quantity of TCA. Moreover, green fungi Pecilomyces sp. and Penicillium chrysogenum had the highest yields of conversion from TCP to TCA $(17 \%-20 \%)$.

The contamination from different microorganisms can begin on trees and continue during wine storage, manufacturing and wine aging. Pesticides used on trees and cork stopper sanitizers containing chlorine compounds were identified as possible causes of contamination [13].

TCA production is caused by many fungi-Penicillium, Aspergillus, Actinomyces and Streptomyces-through the methylation of the corresponding 2,4,6-trichlorophenol, which can derive from chlorine-containing compounds in the cork, among other places. TCA and its precursors can be present in the atmosphere of the cellar coming from common sanitizers containing chlorine, which is why bleach—sodium hypochlorite—should not be used in wine cellars or neighboring environments.

Contamination with chlorophenols caused by fungicides or insecticides may involve woody materials used for the construction or lining of cellars, wooden pallets for bottles, paints, cartons and other materials that can be polluted by oenological adjuvants, bottles, corks and wines. TCA was also identified as a contaminant of oak barrels [14]. In conditions of high humidity and limited ventilation, fungi can transform inodorous chlorophenols with high perception thresholds into chloroanisoles with low perception threshold. In these cases, TCA is not generally present, but it is more common to find 2,3,4,6-tetrachloroanisole (TeCA) with a moldy cellar odor and other molecules such as 2,3,4,6-tetrachlorophenol, 2,3,4,5,6-pentachloroanisole (PCA) and pentachlorophenol [4]. Recently, a study proposed a method to evaluate chloroanisoles and chlorophenols in the cellar atmosphere, in the stoppers, in mini staves, in bottling areas and cap storage units [15]. A review [16] described analytical methods for quantification of haloanisoles and halophenols in the cork matrix. Another one [17] discussed advances in the analysis of musty odor compounds in water and wine. A 2012 review [18] focused on the analytical methods for cork-taint determination in wines. Other authors [19] outlined the methods for chloroanisole determination using gas chromatography-olfactometry and they had a reliable positive response when TCA concentration was above $0.25 \mathrm{ng} / \mathrm{L}$.

Odor detection threshold ODT is the lowest concentration at which a particular odorant is perceivable by the human sense of smell. Odor Recognition threshold: the concentration at which an odorant is not only detected but is also recognized by the human sense of smell (ISO 5492). However, it is difficult for wine tasters to correctly identify TCA in the wine at low concentrations due to fatigue of the sense organs, physiological sensitivities of each taster, professional experience and the influence of the substrate-which can vary the olfactory and gustatory perception of TCA. Its odor is generally described as mold, wet cardboard or mold cellar. As cited before, TCA has also been reported to be an olfactory suppressor of wine odor [7].

Different authors obtained various values of the TCA thresholds. Some assays $[20,21]$ showed that the substrate-type of wine-influences the TCA perception and recognition. In white wines the thresholds are generally lower $(3-7 \mathrm{ng} / \mathrm{L})$ than in the red wines $(8-15 \mathrm{ng} / \mathrm{L})$. If the wine is aged in wood, TCA recognition can be more difficult. Other results [4] reported a TCA perception threshold of $4 \mathrm{ng} / \mathrm{L}$ in both neutral wines and dry white wines. In water, TCA perception thresholds range from 0.03 [22] to 1-2 ng/L [23] for professional tasters or trained assessors.

It is difficult to determine a threshold to which consumers reject a contaminated wine-odor rejection threshold (ORT). An Australian study [24] observed an ORT of $3.1 \mathrm{ng} / \mathrm{L}$ in a white wine, but some consumers had a very high threshold for TCA or do not deem it unpleasant. About $10 \%$ of consumers did not reject a wine with $32 \mathrm{ng} / \mathrm{L}$ of TCA. Others [25] reported that a panel of consumers had an ORT of $10.4 \mathrm{ng} / \mathrm{L}$ for white wines and $16.0 \mathrm{ng} / \mathrm{L}$ for red wines, but ODT and taste detection threshold (TDT), respectively, for TCA were 0.2 and $0.3 \mathrm{ng} / \mathrm{L}$ in water, 0.9 and $1.7 \mathrm{ng} / \mathrm{L}$ for red wines, 1.5 and $1.0 \mathrm{ng} / \mathrm{L}$ for white wines and 4 and $10 \mathrm{ng} / \mathrm{L}$ for hydro-alcoholic solutions with $11.5 \%$ and $18 \%$ ethanol. This group of untrained assessors had very low ODT and TDT, but they did not reject the wine at these concentrations, even if their ORTs were lower. Generally, ODTs are lower than TDTs for TCA. A recent study [26] shows the sensitivity of 34 panelists to some compounds responsible for 
off-flavor in wines and among them 2,4,6-trichloroanisole (TCA). A red wine-a de-aromatized, young, unwooded Shiraz wine- - was added with $4 \mathrm{ng} / \mathrm{L}$ of TCA, but it was not significantly distinguished orthonasally from the same unpolluted wine.

\subsection{2,4,6-Tribromoanisole (TBA)}

TBA is a highly volatile compound with a low perception threshold $-0.5 \mu \mathrm{g} / \mathrm{L}$ in white wines - and an unpleasant odor of mold and mushrooms [27]. It is produced by microorganisms from 2,4,6-tribromophenol (TBP)—a fireproofing agent that can easily spread in the atmosphere [28]. TBA can contaminate wine during vinification, conservation and aging by being in contact with metal capsules treated with a paint containing brome resins or wood barrels and wood chips contaminated by TBA or TBP. Another source can be from air contamination caused by the presence of fireproofing agents containing TBA or TBP. Another source can be cork stoppers preserved in polluted environments. It has been found in wood barrels transported in in ships when containers were treated with fumigants containing brome [14]. It has also been detected in samples of oak staves at a concentration of $8.9 \pm 0.6 \mathrm{ng} / \mathrm{g})$, which would contaminate wine [15].

\section{Geosmin}

Geosmin (trans-1,10-dimethyl-trans-9-decalol) is a sesquiterpene produced by various microorganisms including Bacteria, Protozoa, Actinomycetes, Blue Algae, Mushrooms and Molds (Penicillium). Geosmin has a low perception detection threshold of $5 \mathrm{ng} / \mathrm{L}$ and an identification threshold of $10 \mathrm{ng} / \mathrm{L}$ in water [4].

The name, geosmin derives from Greek meaning odor (osmo) of hearth (geo). It smells of damp earth, humus, red beets, dump cellar and mold. It was first described as a river water pollutant but was soon found in wines made from grapes damaged or contaminated by Botrytis cinerea and Penicillium expansum. It is also a contaminant of foods, fruits, oak wood and cork stoppers. A sensory test with 137 operators of the oenological sector found cases of anosmia when tasting $5 \%$ geosmin in an aqueous solution [29].

The perception thresholds reported in literature vary from $30-45 \mathrm{ng} / \mathrm{L}$ with recognition thresholds from 50-65 ng/L, depending on the type of wine-lower in neutral white wines and highest in aromatic and red wines aged in wood. Geosmin created problems in some regions of France at the beginning of the 21st century [30]. Its concentration does not change during the vinification since it is stable at the wine $\mathrm{pH}$, but in order to lower its content by $50 \%$, wine can be preserved at $20{ }^{\circ} \mathrm{C}$ for 2 months or at $10{ }^{\circ} \mathrm{C}$ for 8 months [31]. Its presence is linked to Penicillium expansum on grapes, but its production takes place on grapes prior to contamination by strains of B. cinerea [32].

Some environmental parameters such as water activity (aw) contribute to influence the physiology of Penicillium expansum and Penicillium carneum toward the production of geosmin [33]. A cork defect detected at a sensory level by a trained panel in Austria was found to be due to geosmin contamination [34].

Treatments were proposed to reduce the concentration of geosmin based on grapeseed oil [35], sorption of enological yeasts [36] and activated carbon [37].

\section{2-Methylisoborneol (2-MIB)}

The contaminant 2-MIB has a low odor detection threshold of $0.006-0.012 \mu \mathrm{g} / \mathrm{L}$ in water and $0.055 \mu \mathrm{g} / \mathrm{L}$ in wine [31] and it was found in few cases in wine [38]. Reports on 2-MIB suggest a detection threshold of $30 \mathrm{ng} / \mathrm{L}$ in white wine with earthy, mushroom, damp earth and camphor odors [4], similar to that of geosmin. Along with geosmin it is a water contaminant and it can be produced by Cyanobacteria. It is also a contaminant of beer due to the use of water contaminated by 2-MIB. It can be produced in cork by Actinomycetes or it can derive from grapes affected by B. cinerea. The presence of 2-MIB in wine was identified to be responsible for the earthy moldy defect of red grapes affected by $B$. cinerea. According to various studies it seems to be instable in wine; it degrades during the process 
of vinification, but also was found in some seven-year-old Burgundy pinot noir wines [39]. In this study, the authors observed that 2-MIB concentration decreases during wine storage, but the final concentration could still be above its odor threshold.

\section{Guaiacol and 4-Methylguaiacol}

These volatile compounds can be found in cork and in the leaves of some grape varietals including Shiraz, Merlot and Muscat of Alexandria [40,41]. In low concentrations they can positively contribute to the aroma and flavor of wines but are considered an off-flavor in high concentrations. Guaiacol has smoked, phenolic and medicinal odors with a perception threshold between $20 \mu \mathrm{g} / \mathrm{L} \mathrm{[4]}$ and $23 \mu \mathrm{g} / \mathrm{L}[26,42]$. Identification thresholds are $75 \mu \mathrm{g} / \mathrm{L}$ in white wines and $95 \mu \mathrm{g} / \mathrm{L}$ in red wines for guaiacol and $65 \mu \mathrm{g} / \mathrm{L}$ in both white and red wines for 4-methylguaiacol [43].

Generally, the degradation of vanillin to vanillic acid to guaiacol is caused by bacterial strains such as Streptomyces present on cork. Guaiacols found in wines stored in wooden barrels are caused by the degradation of lignin.

Guaiacols are also considered indicators of grapes or wines which were in contact with fires [44] — called "smoke taint" in Australia. In these areas the vineyards can be invaded by the smoke of spontaneous fires or induced in the bush, with consequent economic damage due to the loss of product quality with unpleasant odors of dirty, smoked, earthy, burned and smoked meat. Smoke taint can develop during aging caused by the hydrolysis of the corresponding glycosylated compounds. For smoke-tainted wines, guaiacol is usually higher in quantity than 4-methyl-guaiacol.

\section{1-Octen-3-One and 1-Octen-3-O1}

In white wines such as Sauvignon blanc, Pinot Meunier, Pinot gris and Pinot noir, unsaturated ketones-1-octen-3-one and 1-nonen-3-one-can give off-flavors of fresh mushrooms and metal. The 1-octen-3-one compound has a low perception threshold of $20 \mathrm{ng} / \mathrm{L}$ in white wines. It is rare to find these ketones in wines, but sometimes their presence is due to contaminated cork stoppers, wood barrels or grapes with B. cinerea [4].

During alcoholic fermentation, 1-octen-3-one is transformed to 3-octanone, a compound with a very high perception threshold, but much less odorous.

These ketones derive alcohols-1-octen-3-olo and 2-octen-1-olo-due to the degradation of unsaturated fat acids caused by many mushrooms. The alcohol 1-octen-3-ol is considered to be a marker of noble rot in Passito wines [31,45].

Off-flavors of fresh mushrooms caused by 1-octen-3-one were found in wines of different grape varieties in high concentrations of $90-400 \mathrm{ng} / \mathrm{L}$ by gas chromatography coupled with olfactometry [46] in grapes infected with $B$. cinerea. Due to the formation of adducts between 1-octen-3-one and glycine and 1-octen-3-one and glutathione, the addition of these nitrogenous compounds (glycine and glutathione) can decrease the content of 1-octen-3-one in wines and diminish the off-odor. Activated carbons can remove 1-octen-3-one better than chitosans and zeolites [37].

\section{Pyrazines}

\subsection{2-Ethoxy-3,5-Dimethylpyrazine (MDMP)}

MDMP was identified as the second most common compound-after TCA—to cause the cork or mold smell in Australian wines [47]. It has very low perception thresholds of $2.1 \mathrm{ng} / \mathrm{L}$-similar to those of TCA but with different odors. It was identified in cork stoppers and in wines that was in contact with polluted cork stoppers. It was previously recognized in coffee described with earthy odors. MDMP has a water perception threshold of $0.4 \mathrm{ng} / \mathrm{L}$. MDMP can be produced from amino acids by proteobacterium Rhizobium excellensis [48]—a pollutant of cork bark. It was found in wines closed with cork stoppers with off-odors of herbaceous potato, unripe hazelnut or dirt. Contamination with MDMP is not related to the presence of TCA. The main source of pollution are cork stoppers-it 
was reported in $40 \%$ of untreated cork planks at concentrations of about $10 \mathrm{ng} / \mathrm{L}$. Considering the low perception threshold of MDMP, this can be a risk for producers. Other sources of MDMP pollution for wine include the oak wood of chips or barriques, although 93\% of the MDMP is destroyed if the wood treated at $220{ }^{\circ} \mathrm{C}$ for $10 \mathrm{~min}$ [48].

\subsection{Other Pyrazines}

Other pyrazines such as 3-isobutyl-2-methoxypyrazine (IBMP), 3-sec-butyl-2-methoxyipirazine (SBMP) and 3-isopropyl-2-methoxypyrazine (IPMP) can contaminate cork stoppers and give the wine unpleasant vegetable odors-green pepper, peas or potatoes. Pyrazine perception thresholds are low at 2-30 ng/L and detection thresholds are $45-55 \mathrm{ng} / \mathrm{L}$ depending on the wines. A sensory test with 137 operators of the oenological sector found cases of anosmia for 2-isobutyl-3-methoxyipyrazine (3\%) in an aqueous solution [29].

Pyrazines are naturally present in some varietals such as Cabernet Sauvignon and Merlot cultivated in cool climates. If pyrazine content is too high, they are considered a wine defect. Insects are another possible source of pyrazine wine contamination. "Ladybug taint" (LBT) is a wine defect resulting from the undesired incorporation of lady beetles (Coleoptera: Coccinellidae)—particularly the multicolored Asian lady beetle (Harmonia axyridis) — into the fermentation process. This is responsible for high economic damage caused by downgraded or discarded wines in the USA $[49,50]$.

\section{Stoppers, Barriers and Scalping Phenomena}

The amount of 3-alkyl-2-methoxypyrazines in wines can be decreased by contact with absorptive cork, synthetic cork or Tetra Pak cartons [51]. Cork stoppers can determine phenomenon of scalpingsome volatile compounds that have high affinity for the cap tend to be absorbed to reach a balance. This is negative for some aromatic compounds related to wine quality, but it is positive in case of the pyrazines or other sensory unpleasant molecules.

Some authors [52] contaminated a white wine with deuterium-labeled 2,4,6-trichloroanisole (d5-TCA) and then closed the bottles $(n=60)$ with different corks. After thirty months about half of the d5-TCA was absorbed by the corks in different quantities. The corks also contained endogenous TCA and some of them, generally agglomerates, gave their endogenous TCA to the wines. No direct relationship was pointed out between the quantity of the endogenous TCA in corks and in wines, instead the distribution of the d5-TCA was quite uniform; this methodology can distinguish wines tainted prior to closure and wine contaminated by cork stoppers. The study also showed that natural cork stoppers can absorb TeCA and PCA from bottled wines that were polluted before bottling. In addition, direct application of d5-TCA solution on top of the cork and agglomerated stoppers did not lead to wine contamination [53]. It was found that cork stoppers, but not synthetic corks or screw caps, were an effective barrier to airborne volatile compounds, like TCA, ethylphenols and guaiacol [54]. The volatile compounds were retained in the outer portion of the cork and synthetic closures, but the last ones and the screw caps allowed the contamination of the wines.

Some authors [55] showed that the presence of capsules-without open holes-above synthetic stoppers can reduce wine contamination by airborne d5-TCA. They demonstrated that an exposure for 3 months to high air contamination could cause a relevant absorption of d5-TCA by synthetic stoppers, which can subsequently lead to wine contamination after 12 months.

\section{Prevention}

The best solution to avoid these wine defects is the prevention, because the cure is not easy.

For grape contaminants, the only action to avoid them is to use healthy bunches or to select the cluster before vinification.

Recently, the risk to have chloroanisoles and chlorophenols in wines after grape storage or after the use of electrolyzed water in postharvest treatments was demonstrated [56]. 
In the case of other molecules. it is important to keep the wine cellar clean, the storage rooms of the bottles and the caps with sanitizers free of chlorine-and to limit the development of microflora by controlling humidity, ventilation and temperature. Moreover, it is suggested to choose suppliers with high quality controls and check the technical data not only of stoppers, but also for all possible causes of contamination such as dyes, lubricants, sanitizers, inks and pelliculants [57].

In other cases, the wine industry should avoid possible sources of chlorophenol pollution by checking for materials and furnishings that contain wood paints and fungicides before they are used in the construction of wine cellars and annexed rooms.

There is also a "Good practices guide for bulk wine transportation" developed by the International Wine Office (OIV) and adopted by its members States in 2000 [58]. It is based to a large extent on a previous guide published by the Wine and Spirit Association of Great Britain and Northern Ireland in 1994. The scope is to ensure acceptable cleanliness and freedom from any defect or contaminant which could adversely affect the characteristics or quality of the wine being carried, including its authenticity. This advisory guide includes "procedures to which Suppliers and Purchasers on the one hand and Freight Forwarders and Ship Owners on the other, should refer when negotiating contracts concerning bulk wine transport operations. All the practices proposed, subject to their conformity with the applicable regulations in the various regions concerned, are in actual and successful use. With proper application, they contribute to the quality of the wine during transit and to guaranteeing its authenticity".

CELIĖGE or The European Cork Federation represents all the associations of cork producers which established the so-called SYSTECODE, an International Code of Cork Stopper Manufacturing Practice, an international reference for companies involved in production and sale of cork stoppers, but also for the users. On its web site (www.celiege.eu) it is possible to verify the accredited companies of 7 countries (Portugal, Spain, France, Italy, Germany, Morocco, Tunisia) which can offer their customers a guarantee that their products comply with the standards since their production processes were checked ang analyzed objectively.

Generally, before use the cork stopper lots are submitted to a sensory test directly by the winemakers or with the support of a laboratory and the percentage of contaminated cork is defined. It is generally accepted a percentage of contamination of $2 \%$ for a cork stopper lot. If the percentage is higher the lot is rejected.

An Italian disciplinary [59] was developed by various operators of the cork supply chain (Agris-Sardegna. Unione Italiana Vini, Assoimballaggi) and a university (Università Cattolica del Sacro Cuore, Piacenza, Italy) which shows the analytical methods for the control of the cork stoppers. This document gives indications also on the sensory control of cork stoppers before use.

Moreover, there are ISO norms concerning cork, specifically for cork-stopper sensory analyses (ISO 22308-2005).

\section{Cure}

Some experimental methods to remove some compounds, like geosmin, 1-octen-3-one and 1-octen-3-ol form contaminated wines were indicated in the previous sections, but none of them is allowed by U.E. law (Regulation EU 2019/934).

Researchers have proposed different experimental solutions to remove TCA-for example, a patent [60] using activated charcoal obtained from carbons of coconut smells to "remove the cork taste and anomalous smells of cork materials". Another patent [61] proposes aliphatic synthetic polymers (ultra-high molecular weight polyethylene) to lower TCA from food and beverage products.

Highly absorbent yeast cell extracts [62] were added to some wines ( $400 \mathrm{mg} / \mathrm{L})$ stirred 3 times/day and with 2 days of contact. They were able to remove TCA $(27 \%)$, TeCA $(55 \%)$ and PCA $(73 \%)$. The double dose gave better results: $45 \%, 73 \%$ and $83 \%$, respectively. A dose of $100 \mathrm{mg} / \mathrm{L}$ could reduce TCA and TeCA content to concentrations lower than $5 \mathrm{ng} / \mathrm{L}$ and $25 \mathrm{ng} / \mathrm{L}$, respectively.

The use of molecularly imprinted polymers and nonimprinted polymers were also experimented with good results: about $90 \%$ of TCA was removed [63]. 
The aforementioned study [52] showed that plastic materials (polyethylene)—such as the lids of glass containers used to store wine samples-were also able to absorb chloroanisoles through direct liquid contact and via vapor. It was also showed that wine cask bladders and polyethylene film could remove TCA from wine.

All these solutions are not able to completely eliminate TCA and the quality of the wine is not totally preserved. Moreover, they can be expensive or experimented only at a laboratory scale.

In 2011 a cellular biosensor to detect TCA was proposed [64]. It can quickly (3-5 min) detect TCA from cork soaks at very low concentrations of 1.02-12 ng/L), covering the whole range for the detection threshold for wines.

The most recent EU law (Regulation EU 2019/934) admits a treatment using a filter plate containing zeolites Y-faujasite only for the purpose to adsorb haloanisoles. It is subject to the conditions laid down in file 3.2.15 (2016) of the OIV Code of Oenological Practices [58]: it can be applied during filtration to lower the concentration of haloanisoles responsible for off-flavor in wines, below their sensory perception threshold. This treatment should be carried out on clarified wines, the filter plates should be cleaned and disinfected before filtration and the application of zeolites Y-faujasite should comply with the prescriptions in the International Oenological Codex (Zeolite Y- faujasite, COEI-1-ZEOLIT:2016). This treatment is based on a patent [65].

Recently, it has been shown that some polymers (polyanilines) were able to eliminate $75 \%$ of TCA and 13\% TBA in whisky without significative consequences on the aromatic profile and on the total phenolic content [66]. The same team also verified the possibility to use these inexpensive polymeric materials as potential fining agents for elimination of TCA in the beverage industry, through a hybrid strategy of computational and experimental studies [67]. These polymers seem to have some advantages for future practical applications.

Table 1 synthetizes the most important molecules involved in the so-called "cork taint" and the corresponding references cited in this review. 
Table 1. The molecules involved in the so called "cork taint" and the references cited in this review.

\begin{tabular}{|c|c|c|c|}
\hline Molecule & Origin & Odor Description & References \\
\hline 2,4,6-trichloroanisole (TCA) & $\begin{array}{l}\text { Fungi contamination of water, cork, cork stoppers, woody } \\
\text { materials (oak barrels, pallets), paints, cartons, bottles, wines }\end{array}$ & mold, damp cellar, wet cardboard & {$[4,6-26,52-56,60-67]$} \\
\hline 2,4,6-Tribromoanisole (TBA) & $\begin{array}{l}\text { Fungi or air contamination of water, wine, wood barrels or } \\
\text { chips, cork stoppers }\end{array}$ & mold, mushrooms & {$[4,14,15,27,28,65,66]$} \\
\hline Geosmin & $\begin{array}{l}\text { Various microrganisms contamination of water, grapes, oak } \\
\text { wood, and cork stoppers }\end{array}$ & $\begin{array}{l}\text { damp earth, humus, red beets, mold, } \\
\text { dump cellar }\end{array}$ & {$[4,29-37]$} \\
\hline 2-methylisoborneol (2-MIB) & $\begin{array}{l}\text { Actinomycetes contamination of cork or B. cinerea } \\
\text { affected grapes }\end{array}$ & earthy, mushroom, damp earth, camphor & {$[4,31,38,39]$} \\
\hline $\begin{array}{l}\text { Guaiacol } \\
\text { 4-methylguaiacol }\end{array}$ & $\begin{array}{l}\text { Bacteria (Streptomyces) contamination of cork and wood } \\
\text { barrels or "smoke taint" }\end{array}$ & smoked, phenolic, medicine & {$[4,26,40-44,54]$} \\
\hline $\begin{array}{l}\text { 1-octen-3-one } \\
\text { 1-octen-3-ol }\end{array}$ & $\begin{array}{l}\text { Mushrooms contamination of cork stoppers, wood barrels or } \\
\text { B. cinerea affected grapes }\end{array}$ & fresh mushrooms and metal & {$[4,31,37,45,46]$} \\
\hline 2-methoxy-3,5-dimethylpyrazine (MDMP) & Rhizobium excellensis contamination of cork bark & $\begin{array}{l}\text { earthy, herbaceous, potato, unripe } \\
\text { hazelnut, dirty }\end{array}$ & {$[47,48]$} \\
\hline $\begin{array}{l}\text { 3-isobutyl-2-Methoxyipirazine (IBMP), } \\
\text { 3-Sec-butyl-2-methoxyipirazine (SBMP), } \\
\text { 3-isopropyl-2-Methoxyipirazine (IPMP) }\end{array}$ & $\begin{array}{l}\text { Contaminated cork stopper, undesired insects } \\
\text { (Harmonia axyridis) presence during fermentation }\end{array}$ & green pepper, peas, potatoes & {$[29,49-51]$} \\
\hline
\end{tabular}




\section{Conclusions}

In a review of 2011 [68] on the impact of closures on wine post-bottling development, the authors define cork taint one of the most serious off-flavors in wine and they concluded their work writing that the relations between stoppers and wine, the properties of cork taint and scalping phenomena were not all studied. Still now it is possible to conclude this study saying that not all is clear on these subjects, more studies are desirable, including the possible cures of this wine defect.

Using cork stoppers for bottling wines positively impacts on bottle-aging by contributing to wine bouquet but comes with the risk of cork taint. Moreover, cork stoppers production has a relevant economic importance in the cork sector, which has a rule on the environmental protection.

Funding: This research received no external funding.

Conflicts of Interest: The authors declare no conflict of interest.

\section{References}

1. Dettori, S.; Filigheddu, M.R. Cork and Enology. Analysis of the Domestic Chain. Italian J. For. Mt. Environ. 2016, 71, 331-343. [CrossRef]

2. Pereira, H. Cork: Biology, Production and Uses; Elsevier: Amsterdam, The Netherlands, 2007; p. 336, ISBN 978-044452967-1.

3. Gil, L. Cork: A strategic material. Front. Chem. 2014, 2, 16. [CrossRef] [PubMed]

4. Ribéreau, G.P.; Glories, Y.; Maujean, A.; Dubourdieu, D. Trattato di Enologia 2, 4th ed.; Edagricole: Bologna, Italia, 2018.

5. Rocha, S.M.; Coimbra, M.A.; Delgadillo, I. Demonstration of pectic polysaccharides in cork cell wall from Quercus suber L. J. Agric. Food Chem. 2000, 48, 2003-2007. [CrossRef] [PubMed]

6. Rodríguez-Andrade, E.; Stchigel, A.M.; Guarro, J.; Cano-Lira, J.F. Fungal Diversity of Deteriorated Sparkling Wine and Cork Stoppers in Catalonia, Spain. Microorganisms 2019, 8, 12. [CrossRef]

7. Takeuchi, H.; Kato, H.; Kurahashi, T. 2,4,6-trichloroanisole is a potent suppressor of olfactory signal transduction. Proc. Natl. Acad. Sci. USA 2013, 110, 16235-16240. [CrossRef] [PubMed]

8. Wells, D. Organohalogen Taints in Foods; Australian Food \& Grocery Council: Canberra, Australia, 2007; pp. $1-15$.

9. McGarrity, M.J.; McRoberts, C.; Fitzpatrick, M. Identification, cause, and prevention of musty off-flavors in beer. Tech. Q. Master Brew. Assoc. Am. 2003, 40, 44-47.

10. Juanola, R.; Regueiro, J.A.G.; Subirá, D.; Salvadó, V.; Anticó, E. Migration of 2,4,6-trichloroanisole from cork stoppers to wine. Eur. Food Res. Technol. 2004, 220, 347-352. [CrossRef]

11. Salvatella, P.; Prat, C.; Roselló, J.; Anticó, E. Chloroanisoles and Other Chlorinated Compounds in Cork from Different Geographical Areas. Toxics 2019, 7, 49. [CrossRef]

12. Prak, S.; Günata, Z.; Guiraud, J.-P.; Schorr-Galindo, S. Fungal strains isolated from cork stoppers and the formation of 2,4,6-trichloroanisole involved in the cork taint of wine. Food Microbiol. 2007, 24, 271-280. [CrossRef] [PubMed]

13. Simpson, R.F.; Sefton, M.A. Origin and fate of 2,4,6-trichloroanisole in cork bark and wine corks. Aust. J. Grape Wine Res. 2007, 13, 106-116. [CrossRef]

14. Chatonnet, P.; Fleury, A.; Boutou, S. Identification of a New Source of Contamination of Quercus sp. Oak Wood by 2,4,6-Trichloroanisole and Its Impact on the Contamination of Barrel-Aged Wines. J. Agric. Food Chem. 2010, 58, 10528-10538. [CrossRef] [PubMed]

15. Cacho, J.; Nicolas, J.; Viñas, P.; Campillo, N.; Hernandez-Cordoba, M. Control of halophenol and haloanisole concentration in wine cellar environments, wines, corks and wood staves using gas chromatography with mass spectrometry. Aust. J. Grape Wine Res. 2016, 22, 391-398. [CrossRef]

16. Tarasov, A.; Rauhut, D.; Jung, R. "Cork taint” responsible compounds. Determination of haloanisoles and halophenols in cork matrix: A review. Talanta 2017, 175, 82-92. [CrossRef] [PubMed]

17. Callejón, R.; Ubeda, C.; Ríos-Reina, R.; Morales, M.; Troncoso, A.M. Recent developments in the analysis of musty odour compounds in water and wine: A review. J. Chromatogr. A 2016, 1428, 72-85. [CrossRef] [PubMed] 
18. Fontana, A.R. Analytical methods for determination of cork-taint compounds in wine. TrAC. Trends Anal. Chem. 2012, 37, 135-147. [CrossRef]

19. De La Fuente, A.; Lopez, R.; Cacho, J.; Ferreira, V. Evaluation of Gas Chromatography-Olfactometry for Screening Purposes of Wine Off-Flavors; Elsevier BV: Amsterdam, The Netherlands, 2014; pp. 423-428.

20. Mazzoleni, V.; Maggi, L. Effect of wine style on the perception of 2,4,6-trichloroanisole, a compound related to cork taint in wine. Food Res. Int. 2007, 40, 694-699. [CrossRef]

21. Cravero, M.C.; Bonello, F.; Alvarez, M.D.C.P.; Tsolakis, C.; Borsa, D. The sensory evaluation of 2,4,6-trichloroanisole in wines. J. Inst. Brew. 2015, 121, 411-417. [CrossRef]

22. Griffiths, N.M. SENSORY PROPERTIES OF THE CHLORO-ANISOLES. Chem. Senses 1974, 1, 187-195. [CrossRef]

23. Casey, J. Controversies about corks. Aust. N. Z. Grapegrow. Winemak. 2003, 475, 68-74.

24. Prescott, J.; Norris, L.; Kunst, M.; Kim, S. Estimating a "consumer rejection threshold" for cork taint in white wine. Food Qual. Prefer. 2005, 16, 345-349. [CrossRef]

25. Teixeira, M.I.V.; San Romao, M.V.; Bronze, M.R.; Vilas, B.L. 2,4,6-trichloroanisole: A consumer panel evaluation. Cienc. e Tec. Vitivinic. 2006, 21, 53-65.

26. McKay, M.; Bauer, F.; Panzeri, V.; Buica, A. Testing the Sensitivity of Potential Panelists for Wine Taint Compounds Using a Simplified Sensory Strategy. Foods 2018, 7, 176. [CrossRef] [PubMed]

27. Michel, G. Les goûts de bouchon, mise au point. Rev. Fr. Oenol. 2003, 202, 20-22.

28. Chatonnet, P.; Bonnet, S.; Boutou, S.; Labadie, M.-D. Identification and Responsibility of 2,4,6-Tribromoanisole in Musty, Corked Odors in Wine. J. Agric. Food Chem. 2004, 52, 1255-1262. [CrossRef] [PubMed]

29. Tempere, S.; Cuzange, E.; Malak, J.; Bougeant, J.C.; De Revel, G.; Sicard, G. The Training Level of Experts Influences their Detection Thresholds for Key Wine Compounds. Chemosens. Percept. 2011, 4, 99-115. [CrossRef]

30. Dumoulin, M.; Riboulet, J.M. Analyse de géosmine dans les vins: Apport de la microextraction en phase solide (SPME) couplée à l'analyse par GC-MS. Rev. Française Oenol. 2004, 208, 28-30.

31. La Guerche, S.; Dauphin, B.; Pons, M.; Blancard, D.; Darriet, P. Characterization of Some Mushroom and Earthy Off-Odors Microbially Induced by the Development of Rot on Grapes. J. Agric. Food Chem. 2006, 54, 9193-9200. [CrossRef]

32. La Guerche, S.; Chamont, S.; Blancard, D.; Dubourdieu, D.; Darriet, P. Origin of (-)-Geosmin on Grapes: On the Complementary Action of Two Fungi, Botrytis Cinerea and Penicillium Expansum. Anton. Leeuw. 2005, 88, 131-139. [CrossRef]

33. Ribéreau, G.P.; Glories, Y.; Maujean, A.; Dubourdieu, D. 8.8.2 La (-) geosmina principale composto responsabile del difetto terroso. In Trattato di Enologia 2, 4th ed.; Edagricole: Bologna, Italia, 2018; pp. 307-311.

34. Weingart, G.; Schwartz-Zimmermann, H.; Eder, R.; Sontag, G. Determination of geosmin and 2,4,6-trichloroanisole in white and red Austrian wines by headspace SPME-GC/MS and comparison with sensory analysis. Eur. Food Res. Technol. 2010, 231, 771-779. [CrossRef]

35. Lisanti, M.T.; Gambuti, A.; Genovese, A.; Piombino, P.; Moio, L. Earthy off-flavour in wine: Evaluation of remedial treatments for geosmin contamination. Food Chem. 2014, 154, 171-178. [CrossRef]

36. Pradelles, R.; Chassagne, D.; Vichi, S.; Gougeon, R.; Alexandre, H. (-)Geosmin sorption by enological yeasts in model wine and FTIR spectroscopy characterization of the sorbent. Food Chem. 2010, 120, 531-538. [CrossRef]

37. Behr, M.; Cocco, E.; Lenouvel, A.; Guignard, C.; Evers, D. Earthy and Fresh Mushroom Off-Flavors in Wine: Optimized Remedial Treatments. Am. J. Enol. Vitic. 2013, 64, 545-549. [CrossRef]

38. Ferreira, V.; Juan, F.S.; Escudero, A.; Culleré, L.; Zurbano, P.F.; Sáenz-Navajas, M.-P.; Cacho, J. Modeling Quality of Premium Spanish Red Wines from Gas Chromatography-Olfactometry Data. J. Agric. Food Chem. 2009, 57, 7490-7498. [CrossRef] [PubMed]

39. Pinar, A.L.; Ghadiriasli, R.; Darriet, P.; Buettner, A. Unexpected impact of 2-methylisoborneol as off-odour substance in aged wines. Food Chem. 2017, 220, 498-504. [CrossRef]

40. Sefton, M. Hydrolytically-released volatile secondary metabolites from a juice sample of Vitis vinifera grape cvs Merlot and Cabernet Sauvignon. Aust. J. Grape Wine Res. 1998, 4, 30-38. [CrossRef]

41. Wirth, J.; Guo, W.; Baumes, R.; Günata, Z. Volatile compounds released by enzymatic hydrolysis of glycoconjugates of leaves and grape berries from Vitis vinifera Muscat of Alexandria and Shiraz cultivars. J. Agric. Food Chem. 2001, 49, 2917-2923. [CrossRef] 
42. Parker, M.; Osidacz, P.; Baldock, G.A.; Hayasaka, Y.; Black, C.A.; Pardon, K.H.; Jeffery, D.W.; Geue, J.P.; Herderich, M.J.; Francis, L. Contribution of Several Volatile Phenols and Their Glycoconjugates to Smoke-Related Sensory Properties of Red Wine. J. Agric. Food Chem. 2012, 60, 2629-2637. [CrossRef]

43. Boidron, J.-N.; Chatonnet, P.; Pons, M. Influence du bois sur certaines substances odorantes des vins. OENO One 1988, 22, 275. [CrossRef]

44. Singh, D.; Chong, H.; Pitt, K.; Cleary, M.; Dokoozlian, N.; Downey, M. Guaiacol and 4-methylguaiacol accumulate in wines made from smoke-affected fruit because of hydrolysis of their conjugates. Aust. J. Grape Wine Res. 2011, 17, S13-S21. [CrossRef]

45. Simonato, B.; Lorenzini, M.; Cipriani, M.; Finato, F.; Zapparoli, G. Correlating Noble Rot Infection of Garganega Withered Grapes with Key Molecules and Odorants of Botrytized Passito Wine. Foods 2019, 8, 642. [CrossRef]

46. Pons, M.; Dauphin, B.; La Guerche, S.; Pons, A.; Lavigne-Cruege, V.; Shinkaruk, S.; Bunner, D.; Richard, T.; Monti, J.-P.; Darriet, P. Identification of Impact Odorants Contributing to Fresh Mushroom Off-Flavor in Wines: Incidence of Their Reactivity with Nitrogen Compounds on the Decrease of the Olfactory Defect. J. Agric. Food Chem. 2011, 59, 3264-3272. [CrossRef]

47. Simpson, R.F.; Capone, D.L.; Sefton, M.A. Isolation and Identification of 2-Methoxy-3,5-dimethylpyrazine, a Potent Musty Compound from Wine Corks. J. Agric. Food Chem. 2004, 52, 5425-5430. [CrossRef] [PubMed]

48. Chatonnet, P.; Fleury, A.; Boutou, S. Origin and Incidence of 2-Methoxy-3,5-dimethylpyrazine, a Compound with a "Fungal" and "Corky" Aroma Found in Cork Stoppers and Oak Chips in Contact with Wines. J. Agric. Food Chem. 2010, 58, 12481-12490. [CrossRef] [PubMed]

49. Pickering, G.; Lin, J.; Riesen, R.; Reynolds, A.; Brindle, I.; Soleas, G. Influence of Harmonia axyridis on the sensory properties of white and red wine. Am. J. Enol. Vitic. 2004, 55, 153-159.

50. Pickering, G.J.; Lin, Y.; Reynolds, A.; Soleas, G.; Riesen, R.; Brindle, I. The Influence of Harmonia axyridison Wine Composition and Aging. J. Food Sci. 2005, 70, S128-S135. [CrossRef]

51. Blake, A.; Kotseridis, Y.; Brindle, I.; Inglis, D.; Sears, M.; Pickering, G.J. Effect of Closure and Packaging Type on 3-Alkyl-2-methoxypyrazines and Other Impact Odorants of Riesling and Cabernet Franc Wines. J. Agric. Food Chem. 2009, 57, 4680-4690. [CrossRef]

52. Capone, D.L.; Skouroumounis, G.K.; Barker, D.; McLean, H.; Pollnitz, A.P.; Sefton, M. Absorption of chloroanisoles from wine by corks and by other materials. Aust. J. Grape Wine Res. 1999, 5, 91-98. [CrossRef]

53. Capone, D.L.; Skouroumounis, G.K.; Sefton, M.A. Permeation of 2,4,6-trichloroanisole through cork closures in wine bottles. Aust. J. Grape Wine Res. 2002, 8, 196-199. [CrossRef]

54. Pereira, B.; Lopes, P.; Marques, J.; Pimenta, M.; Alves, C.; Roseira, I.; Mendes, A.M.; Cabral, M. Sealing effectiveness of different types of closures towards volatile phenols and haloanisoles. OENO One 2013, 47, 145. [CrossRef]

55. Tarasov, A.; Rauhut, D.; Jung, R. Bottle capsules as a barrier against airborne 2,4,6-trichloroanisole. Food Chem. 2018, 268, 463-467. [CrossRef]

56. Giacosa, S.; Gabrielli, M.; Torchio, F.; Segade, S.R.; Grobas, A.M.M.; Aimonino, D.R.; Gay, P.; Gerbi, V.; Maury, C.; Rolle, L. Relationships among electrolyzed water postharvest treatments on winegrapes and chloroanisoles occurrence in wine. Food Res. Int. 2019, 120, 235-243. [CrossRef] [PubMed]

57. Tablino, L. Cosa si nasconde dietro i tappi? Vignevini 2010, 38, 52-56.

58. OIV Part III Good Practices Guide for Bulk Wine Transportation, in International Code of Oenological Practices. 2019; p. 431. Available online: http://www.oiv.int/public/medias/6558/code-2019-en.pdf (accessed on 26 February 2020).

59. A.A.V.V. Nuovo Disciplinare Sulle Metodiche Analitiche per il Controllo del Tappo di Sughero ad Uso Enologico; Crugnola Comunicazione e Design: Milano, Italia, 2011; p. 42.

60. Cioni, G.A.; Cadinu, T. Physical Chemical Method to Remove the Cork Taste and in General Anomalous Smells of Cork Materials. WIPO Patent 2001 WO/2001/041989A2, 14 June 2001.

61. Swan, J.S. Process for Removing Off-Flavors and Odors from Foods and Beverages. U.S. Patent US6610342B22003, 2003.

62. Vuchot, P.; Puech, C.; Fernandez, O.; Fauveau, C.; Pellerin, P.; Vidal, S. Elimination des goûts de bouchon/moisi et de l'OTA à l'aide d'écorces de levures hautement adsorbantes. Rev. Vitic. Oenol. 2007, 2, 62-72. 
63. Garde-Cerdán, T.; Zalacain, A.; Lorenzo, C.; Alonso, J.L.; Salinas, M.R. Molecularly imprinted polymer-assisted simple clean-up of 2,4,6-TCA and ethylphenols from aged red wines. Am. J. Vitic. Enol. 2008, 59, 396-400.

64. Varelas, V.; Sanvicens, N.; Marco, M.-P.; Kintzios, S. Development of a cellular biosensor for the detection of 2,4,6-trichloroanisole (TCA). Talanta 2011, 84, 936-940. [CrossRef]

65. Cunningham, J. Highly Selective Molecular Confinement for the Prevention and Removal of Taint in Foods and Beverages. US Patent WO 2007/061602 A1, 31 May 2007.

66. Valdés, O.; Marican, A.; Avila-Salas, F.; Castro, R.; Amalraj, J.; Laurie, V.F.; Santos, L.S. Polyaniline Based Materials as a Method to Eliminate Haloanisoles in Spirits Beverages. Ind. Eng. Chem. Res. 2018, 57, 8308-8318. [CrossRef]

67. Valdés, O.; Marican, A.; Avila-Salas, F.; Castro, R.; Mirabal, Y.; Amalraj, J.; Abril, D.; Durán-Lara, E.F.; Santos, L.S. Simple approach for cleaning up 2,4,6-trichloroanisole from alcoholic-beverage-reconstituted solutions using polymeric materials. Aust. J. Grape Wine Res. 2019, 25, 327-337. [CrossRef]

68. Silva, M.A.; Julien, M.; Jourdes, M.; Teissedre, P.-L. Impact of closures on wine post-bottling development: A review. Eur. Food Res. Technol. 2011, 233, 905-914. [CrossRef]

(C) 2020 by the author. Licensee MDPI, Basel, Switzerland. This article is an open access article distributed under the terms and conditions of the Creative Commons Attribution (CC BY) license (http://creativecommons.org/licenses/by/4.0/). 